\title{
MARKETING OF ALBERTA GAS FOR EXPORT UNDER DEREGULATION
}

\author{
DONALD C. EDIE*
}

\begin{abstract}
This paper examines the current regulatory framework respecting the export of Alberta natural gas to United States markets. It contains an outline of the current Canadian and certain American regulatory requirements to be fulfilled, discusses producer concerns respecting some effects of certain of these requirements and briefly raises certain practical concerns respecting available pipeline capacity required to transport natural gas from Alberta to the United States.
\end{abstract}

\section{INTRODUCTION}

For they have sown the wind and they shall reap the whirlwind'

Twelve years ago the Canadian and Alberta Governments entered the field of gas pricing regulation in a wholehearted way. Now they are attempting to remove themselves from this arena and are finding it is not so simple to leave as it was to enter. The winds of the mid-seventies which sprang from the competing producer and consumer interests have escalated into a whirlwind of parties of diverse interests seeking furtherance of their positions before regulatory bodies.

The Governments of Canada and Alberta have stressed that due to the monopolistic nature of gas transmission, the transmission segment of the natural gas industry will not be deregulated. Rather, pricing of natural gas as a commodity in the domestic market will be deregulated, to the extent consistent with the continuing regulation of the gas transmission function. ${ }^{2}$ However, public policy dictates the continuing active presence of the National Energy Board (the "NEB") in at least three areas of the gas export business: by its regulation of the interprovincial transmission utilities; its determination of Canadian requirements for natural gas; and in the monitoring of the price of domestic natural gas supplies versus the price of exported natural gas.

This paper discusses some practical constraints on the transmission of new firm natural gas exports and examines the current Alberta and federal regulatory requirements to be fulfilled to enable the export of natural gas from Alberta to the United States. It also briefly reviews recent developments in the United States of interest to Canadian producers.

\section{CONTRACTUAL AND PHYSICAL CONSTRAINTS ON NEW FIRM SALES}

For most, if not all, of the export points for natural gas from Canada to the United States physical capacity is not presently a constraining factor. Recent sales of natural gas into the export market have dropped dramati-

- Partner, Parlee McLaws, Calgary, Alberta.

1. Hosea Ch. 8, v. 7, as quoted in J. Clavell, Whirlwind (1986) plate page to Book One.

2. "Agreement among the Governments of Canada, Alberta, British Columbia and Saskatchewan on Natural Gas Markets and Prices" 31 October, 1985, "Objectives of Agreement" at 2. The text of this Agreement is published in Canada Energy Law Service, Hunt et al Editors, Canadian Institute of Resources Law, Richard De Boo Publishers, Volume II, at 30-1806 et. seq. 
cally. Appendix " $\mathrm{A}$ " export markets during the years 1985 and 1986. Appendix " $B$ " identifies the physical capacity by exit point on the international border, as of June, 1987. However, significant contractual constraints exist.

\section{A. ON THE NOVA, AN ALBERTA CORPORATION SYSTEM}

Effective November 1, 1986, NOVA, AN ALBERTA CORPORATION ("NOVA") altered its tariff respecting transportation of gas, on a firm basis to the Alberta border for ultimate consumption outside the province, from the previous "postage stamp" rate to a two-part firm toll (Rate Schedule T5). This tariff contains a Monthly Demand Charge comprising all fixed costs and based upon maximum daily contracted volumes, and a Commodity Charge comprising variable costs. ${ }^{4}$ An integral part of the new NOVA regime was the conversion of service contracts to long- or shortterm firm transportation agreements. By April, 1987, contracts had been entered into for the total NOVA system capacity at Empress, comprising some 4.5 billion cubic feet per day. Eighty-five percent of these firm contracts are for long-term service (minimum 15 years) and fifteen percent are for short-term firm service. ${ }^{3}$ Short-term firm service is offered by NOVA for a one to two year term, but only in those circumstances where no additional facilities are required. ${ }^{6}$

This fully-contracted situation creates a problem for any person wishing to contract with NOVA for firm space on its system for the purpose of facilitating a short-term direct sale. Mitigating this contractual constraint is the fact that, at present, there is no physical constraint preventing the movement of all volumes requested by present and new shippers. ${ }^{7}$

NOVA has proposed a two-fold solution to this problem. First, it has requested all firm shippers to elect to de-contract some of their firm space. Secondly, based upon the lack of physical constraint upon its system, it proposes to "overcontract" the firm space at Empress. This solution would apply with respect to that amount of firm space which does not become available by virtue of de-contracting by current firm shippers. The purpose of this "overcontracting" approach is to attempt to mirror the events occurring, primarily in Ontario, downstream of the Alberta border. ${ }^{8}$ NOVA has indicated that this "overcontracted space" contract would be available to any person who has entered into a contract for firm space on the TransCanada PipeLines Limited ("TCPL") system. ${ }^{9}$ Conceptually, the

3. Appendices "A" and "B": Attachments to Notes to a Speech to International Research Center for Energy and Economic Development entitled "Issues in the Canadian-U.S. Energy Relationship" given by Dale A. Lucas, Chairman, Alberta Petroleum Marketing Commission, dated 23 April 1987. The author expresses appreciation to the APMC for its permission to reproduce these maps as Appendices to this paper.

4. "Gas Transportation Tariff of NOVA, AN ALBERTA CORPORATION" effective 1 November 1986, Tab 7 "Rates Schedule T-5" at 123.

5. Telephone interview, Bryan Curtis, Manager, Rates and Contract Administration, NOVA, AN ALBERTA CORPORATION, 13 May 1987.

6. Supra n. 4, Tab 7 at 120.

7. Supran. 5.

8. Id.

9. Id. 
tolls collected from "overcontracted space" shippers would, in the shortterm, result in demand charge credits to all firm shippers (including the "overcontracted space" shippers) through a monthly credit based upon that shipper's contract demand divided by the total system contract demand and, upon the next striking of new tolls by NOVA, in lower firm tolls overall. ${ }^{10}$ As a precautionary measure against eventual physical capacity constraints, NOVA anticipates making firm contracts for "overcontracted space" conditional upon physical capacity constraints."

From a direct seller's point of view, such a condition would render NOVA's "overcontracted space" short-term firm contract suspiciously akin to an interruptible contract, which NOVA also offers under Rate Schedule T-6 on the basis of a Commodity Rate only, without a Demand Charge. ${ }^{12}$

\section{B. ON THE TRANSCANADA PIPELINES LIMITED SYSTEM}

Prior to 1986, and its flurry of applications for export licences before the National Energy Board, the TCPL system had some minor spare capacity east of Station 41 (connection south to Emerson, Manitoba). TCPL's 1988 Facilities Application ${ }^{13}$ identifies new firm export volumes, in the aggregate, of an additional 503 million cubic feet per day ("MMcfd").$^{14}$ Fifty MMcfd of these volumes are scheduled to commence November 1, 1987 at Emerson, Manitoba, with the remaining $453 \mathrm{MMcfd}$ utilizing sections of the TCPL system east of Station 41. Sufficient spare firm capacity does not exist on the TransCanada system east of Station 41 to carry these additional volumes, together with existing exports and domestic requirements. As a result, TCPL's 1988 Facilities Application contains proposals respecting new facilities which would be necessary to accommodate its total system firm requirements during the 1988-89 contract year. For a more detailed representation of TCPL's anticipated system requirements versus capacity, on a section basis, assuming construction of all facilities contained in its 1988 Facilities Application, see Appendix "C".

The total capacity of the TCPL system from the Alberta border to the export point at Emerson, Manitoba has not been contracted for at the present time. Firm space is, therefore, available from the Alberta border, at Empress, to Emerson, should it be required by an exporter willing to sign a firm transportation contract with TCPL.

\section{ON THE ALBERTA NATURAL GAS COMPANY LTD. SYSTEM}

All firm capacity on the Alberta Natural Gas Company Ltd. ("ANG") system is presently contracted, principally to two parties, Alberta \&

10. Id.

11. Id.

12. Supra n. 4, Tab 8 "Rates Schedule T-6" at 140 and 141.

13. TransCanada PipeLines Limited 1988 Facilities Application, dated January, 1987.

14. New export requirements identified in TransCanada PipeLines Limited's 1988 Facilities Application: Minnegasco Inc., 50 MMcfd at Emerson, Manitoba; Iriquois Gas Transmission System, 352 MMcfd near Iriquois, Ontario; Tennessee Gas Pipeline Co., 41.5 MMcfd at Niagara Falls, Ontario; Shell Canada Limited, 35 MMcfd at Niagara Falls, Ontario and 25 MMcfd at Highwater, Quebec, Tab "Facilities" at 1 and 2. 
Southern Gas Co. Ltd. and Westcoast Transmission Company Limited. ${ }^{15}$ Interruptible capacity is available on the ANG system for persons wishing to export to the Pacific Northwest states. ${ }^{16}$

\section{ON THE FOOTHILLS PIPE LINES (YUKON) LTD. SYSTEM}

The Foothills west leg through south-eastern British Columbia comprises capacity of $240 \mathrm{MMcfd} .{ }^{17}$ At present, this leg is fully contracted on a firm basis. ${ }^{18}$ The Foothill east leg through southern Saskatchewan to the export point at Monchy, Saskatchewan contains capacity of 1,075 MMcfd. Firm contracts exist with respect to $975 \mathrm{MMcfd} .^{19}$ Thus, $100 \mathrm{MMcfd}$ is available for new firm contracts.

Foothills does not presently offer interruptible transportation service on either leg of its system but on June 15, 1987 filed an application with the National Energy Board for an Order amending its gas transportation tariff to, among other things, include an interruptible rate. ${ }^{20}$

\section{DOMESTIC REGULATORY REQUIREMENTS}

\section{A. ALBERTA REMOVAL PERMIT}

Under the authority of the Gas Resources Preservation Act, ${ }^{21}$ subject to the approval of the Lieutenant Governor in Council or the Minister, as the case may be, the Energy Resources Conservation Board is charged with the task of issuing Removal Permits. Section 8 of that Act prohibits the ERCB from granting a removal permit:

unless in its opinion it is in the public interest of Alberta to do so having regard to

(a) the present and future needs of persons in Alberta,

(b) the established reserves and the trends in growth and discovery of reserves of gas or propane in Alberta, and

(c) any other matters considered relevant by the Board.

Prior to March of 1987, for a period of some seven years, the ERCB ascertained the present and future needs of persons in Alberta on the basis of a $25 \mathrm{~A}_{1}$ reserves test, plus a deliverability test. Gas found to be surplus under these tests was available to be exported from the Province.

In March, 1987, the ERCB issued Report 87-A, in which it decided that in determining the aggregate amount of gas available to be subject to removal permits, the mandated surplus test would continue to be applied, but on the basis of $15 C_{1}$ (or 15 times estimate of "Core requirements" use in the first year). ${ }^{22}$ Core requirements are defined as residential require-

15. Telephone interview T. Benson, Counsel for Alberta and Southern Gas Co. Ltd., 6 May 1987.

16. Id.

17. Telephone interview A. Palmer, Manager, Rates and Economics for Foothills Pipe Lines (Yukon) Ltd., 11 May 1987.

18. Id.

19. Id.

20. Letter dated 15 June 1987 from Foothills Pipe Lines (Yukon) Ltd. to the National Energy Board, with Application attached.

21. Gas Resources Preservation Act, S.A. 1984, c. G-3.1, as am. S.A. 1986, c. 17, s. 4, and S.A. 1987, c. 23, infra n. 29.

22. Energy Resources Conservation Board Report 87-A, "Gas Supply Protection for Alberta: Policies and Procedures" March, 1987 at 20. 
ments, plus commercial requirements, plus small industrial requirements (which are in turn defined as individually less than two petajoules per year). ${ }^{23}$ The core users are considered to be those who cannot reasonably be expected to contract for their own supplies of natural gas for their own fuel requirements, but who would normally rely on their local distribution company to contract for gas on their behalf. The ERCB reports that this approach provides a degree of protection for the core markets similar in magnitude to the length of contracts presently entered into by the utilities on their behalf. ${ }^{24} \mathrm{At}$ the same time, this approach allows and requires large industrial users, who are capable of doing so, to provide for their own protection, through contracting for that security of supply each feels is necessary and for which it is willing to pay. In Report 87-A, the ERCB also eliminated the deliverability test requirement but elected to continue the recently adopted policy of increased surveillance of removals of gas under existing permits. ${ }^{25}$

Section 6 of the Gas Resources Preservation $\mathrm{Act}^{26}$ allows the ERCB, with the approval of the Minister (of Energy), to issue "short-term" removal permits involving volumes of gas not to exceed $310^{9} \mathrm{~m}^{3}$ of gas for a period not to exceed two years. In Report 87-A, the ERCB determined that it would continue to process these applications for small volume removal permits, through expedited proceedings. ${ }^{27}$ It also provided for a third category respecting "spot sales", involving total volumes of less than 1 $10^{9} \mathrm{~m}^{3}$, with a maximum term of four months, non-renewable. ${ }^{28}$ Additionally, at the time of writing, Bill 45 is before the Alberta Legislature. This Bill would allow the promulgation of regulations respecting the terms and conditions to which permits or any class of permits are subject, both prospectively and retroactively. ${ }^{29}$

\section{B. NEB EXPORT REQUIREMENTS}

\section{Export Licences}

Part VI of the National Energy Board $\mathrm{Act}^{30}$ deals with the exportation and importation of oil, natural gas and electric power. Section $81^{31}$ prohibits any person from exporting, inter alia, natural gas, except under the authority of and in accordance with a licence. Section $82^{32}$ empowers the NEB to issue licences for both the exportation and importation of, inter alia, natural gas. Section $83^{33}$ specifies that the NEB "shall have regard to

23. Id. at 17, para. 3.3.1(5).

24. Id. at 16, para. 3.2.2.

25. Id. at 20.

26. Supra n. 21, s. 6(1).

27. Supra n. 22 at 18, para. 3.3.4.

28. Id. at 19, para. 3.3.4.

29. 1987 Bill 45, the Gas Resources Preservation Amendment Act, 1987, s. 2(b) and (c), enacted as S.A. 1987, c. 23, Royal Assent given on 17 June 1987. The Permit Conditions Regulation, Alta. Reg. 271/87 was made on 25 June 1987.

30. R.S.C. 1970 , c. N-6, as am.

31. S.C. $1980-81-82-83$, c. 116, s. 23.

32. Id. s. 24.

33. R.S.C. 1970 (1st Supp.) c. 27, c. 28; id. s. 25. 
all considerations that appear to it to be relevant" to an application for an export licence. That section then delineates the specific matters to be examined, including the requirement that the Board shall:

(a) satisfy itself that the quantity of oil, gas or power to be exported does not exceed the surplus remaining after due allowance has been made for the reasonably foreseeable requirements for use in Canada having regard, in the case of an application to export oil or gas, to the trends in the discovery of oil or gas in Canada.

One of the more difficult questions to address in obtaining an export licence is the determination of what constitutes gas "surplus" to reasonably foreseeable requirements for use in Canada. The proper determination of "surplus" gas was the subject of the extensive hearings called under NEB Hearing Order No. GH-2-85..$^{34}$ The Reasons for Decision, dated April, 1986, established a surplus determination formula based upon a complex fifteen-year reserves to production ratio and deliverability (productive capacity) formula. ${ }^{35}$ However, this formula may well be shortlived, as surplus determination was again the subject matter of the 1987 NEB Omnibus Surplus Determination Hearing. This opinion is based in large part upon the expression of anticipation that this NEB review will ultimately result in "significantly freer access to domestic and export markets and thus will contribute to the achievement of the market-oriented pricing system" contemplated in the Agreement entitled "Agreement among the Governments of Canada, Alberta, British Columbia and Saskatchewan on Natural Gas Markets and Prices" dated October 31, 1985 (herein referred to as "the October 31, 1985 Intergovernmental Agreement")..$^{36}$

The vast majority of requirements to be fulfilled prior to obtaining a natural gas export licence arise through regulations. Section $85^{37}$ of the NEB Act empowers the Governor in Council to make regulations respecting matters pertinent to the granting of licences for the exportation of natural gas, including, inter alia, price. Section 4 of the National Energy Board Part VI Regulation $s^{38}$ details an extensive list of information required to be filed in support of an application for an export licence. The information required to support an application for an export licence has not been abridged by the expressed intentions of federal and provincial governments to move toward deregulated pricing of natural gas.

\section{Export Licence Extensions}

An existing export licence holder may apply to the NEB for an amendment to its licence. The prime impellor of recent applications for extension of licences involves so called "trapped gas". Trapped gas is gas which has previously been dedicated to a particular export licence (thereby removing those volumes from the general surplus available for export by

34. National Energy Board Hearing Order GH-2-85 dated 1 August 1985.

35. National Energy Board, "Reasons for Decision, In the Matter of Phase 1 of The Surplus Determination Procedures Phase of the Gas Export Omnibus Hearing, 1985" April 1986, published by the Minister of Supply and Services Canada, 1986, as Cat. No. NE22-1/1986$6 \mathrm{E}, \mathrm{c} .4$.

36. Supra n. 2 at 3 , para. 16.

37. Supra n. 30, s. 85, as am. supra n. 31 , s. 27.

38. C.R.C. 1978, c. 1056, as am. inter alia, SOR/79-30. 
others) but which, due to lack of market, has not been exported under the license in question and, under the maximum daily and annual volumes allowed under the existing licence, could not be exported during its remaining term. The licence holder may, therefore, apply for an extension of its licence, to allow the ultimate export of these trapped gas volumes under an amended licence. This procedure is seen to be a shortcut, as the alternative would be a new application for an export licence in respect of the trapped gas volumes, with all of the hurdles discussed in the previous section of this paper.

A potentially contentious issue may arise between the holder of an export licence, under which is encompassed trapped gas volumes on the one hand, and corporations sponsoring competing proposals on the other. In the event that the NEB determines that few, if any, "surplus" volumes remain to be exported, conflict may result where a corporation, other than the licencee, is the sponsor of a project competing with that of the licencee and perceives that the licencee might gain a competitive advantage. This advantage is perceived to accrue by virtue of the licencee being required to comply only with the expedited procedures respecting amendment of the existing licence to allow "rollover" of the trapped gas volumes, whereas the sponsor of the competing project must make a complete new application for an export licence.

The NEB position respecting the extension of existing export licences to allow a licencee to export trapped gas volumes not previously taken under the licence is expressed in its Reasons for Decision in Alberta and Southern Gas Co. Ltd. ${ }^{39}$ There, the Board expressed its intention not to allow the "automatic rollover" of volumes under existing licences. ${ }^{40}$ In those Reasons for Decision and in the ProGas Reasons for Decision ${ }^{41}$ issued at the same time, the NEB indicated that it would continue to deal with licence extension applications on a case-by-case basis and would take into account several factors, including: ${ }^{42}$

\footnotetext{
... the expectable surplus during the period for which the extension is requested; any alternative export markets [i.e. competing ventures] for the gas in question; the effect on, need for, and utilization of pipeline facilities; the expectation that the gas being considered will be taken; and any particular commercial features of the export market to be served.
}

From this list of requirements, one can conclude that the NEB wishes to disabuse any current licence holder, and any competitors who might require the "surplus" designation for volumes with respect to which they wish to obtain an export licence, of the notion that an application to extend an existing export licence represents the inside track, with respect to trapped gas.

39. National Energy Board, "Reasons for Decision, In the Matter of Alberta and Southern Gas Co. Ltd.: Consolidation of Licences GL-3, GL-16, GL-24, GL-35, GL-67, GL-68 and GL-69 including a Term Extension and Certain Other Changes" October 1986, published by the Minister of Supply and Services Canada, 1986, as Cat. No. NE22-1/1986-12E.

40. Id. at 2, para. 1.5.

41. National Energy Board, "Reasons for Decision In the Matter of Progas Limited Amendment to Licence GL98" October 1986, published by the Minister of Supply and Services Canada, 1986, as Cat. No. NE22-1/1986-11E at 6, para. 3.1.

42. Id. 


\section{Short-Term Orders}

In addition to long-term licences, the NEB may allow the export of natural gas pursuant to short-term Orders. A brief historical summary follows. From 1978 to November of 1985, a short-term Order to export gas could be obtained. However, each Order was restricted to a period not exceeding twelve months and to a volumetric maximum of $6010^{6} \mathrm{~m}^{3}$ of gas. ${ }^{43}$ In 1982, an additional restriction was imposed, wherein the total quantity of gas exported under all short-term Orders could not exceed three billion cubic metres in any twelve-month period. ${ }^{44}$ In November of 1985, in accordance with the October 31, 1985 Intergovernmental Agreement, ${ }^{45}$ the Part VI Regulations were amended to remove the individual and aggregate volumetric restrictions upon short-term export Orders and to increase the maximum term of such Orders to 24 months. ${ }^{45}$ Additionally, the policy requirement that the price of gas exported under short-term Order be not less than the price at the Toronto city gate ${ }^{47}$ was relaxed somewhat, such that the price of gas exported is not to be less than that paid by Canadians for similar types of service in the area adjacent to the point of export. ${ }^{48}$ The requirement that any new export volumes be incremental to existing volumes was also removed at that time. ${ }^{49}$ The "Adjacent Border Area" minimum price test was further relaxed in October, 1986, with the implementation of a post facto review of prices. ${ }^{50}$

\section{FUTURE CONSIDERATIONS}

On April 23, 1987, Mr. M.F. Kanik, the Deputy Minister of Energy for the Province of Alberta sent letters to industry producer associations identifying two problems respecting the existing natural gas royalty system in Alberta. He identified these problems as royalty administration and monitoring problems due to the proliferation of sellers, arrangements and prices following deregulation, and "the role of the royalty system and the potential impact the system might have in promoting lower prices". ${ }^{31}$ This letter and the attached memorandum identify a concern with the complexity of the current gas royalty system. Through these documents, the Department of Energy further solicits producer views respecting the amendment of the system on the criteria of certainty, cost of compliance and administration and acceptability, in terms of capability of being

\footnotetext{
43. Supra n. 38, s. 8, as am. SOR/79-30, s. 2.

44. SOR/82-1028, s. 1.

45. Supra $\mathrm{n} .2$ at para. 17.

46. SOR/85-1049, s. 1 .

47. Canada Energy Law Service, supra n. 2, Volume I at 10-1576 and 1577, referencing: Canada, Department of Energy, Mines and Resources, Communique 84/81, 13 July 1984.

48. Supra n. 46.

49. Id. and supra n. 47 at 10-1576.

50. SOR/86-1052, s. 1, and "Regulatory Impact Analysis Statement" published therein.

51. Letter, 23 April 1987 from M.F. Kanik, Deputy Minister of Energy to IPAC, with attachment; letter, 23 April 1987 from M.F. Kanik, Deputy Minister of Energy to Canadian Petroleum Association, with attachment; letter 23 April 1987 from M.F. Kanik, Deputy Minister of Energy to SEPAC, with attachment.
} 
understood and perceived as fair and reasonable. ${ }^{52}$ Written submissions have been requested to be forwarded by June 15,1987 .

While it is unknown at the present time what the ultimate effect of this review and revision of the Alberta gas royalty system will be on natural gas exports to the United States, recent experience shows that any change causes ripple effects. The only questions are whether the effects will be beneficial or detrimental to natural gas exporters and the magnitude of those effects.

\section{U.S. MATTERS}

The concerns relevant to anyone wishing to market Alberta natural gas in the United States are many and varied; so much so that to attempt to deal with them as part of this paper would not be adequate and might be misleading. However, it should be noted that one issue has been thrust into the forefront in the past few months. The question of the "as billed" passthrough of Canadian gas costs by American pipeline companies to their downstream customers has been before U.S. regulatory agencies for some time..$^{33}$

On May 15, 1986, the U.S. Economic Regulatory Administration ("ERA") issued its decision in Natural Gas Pipeline Company of America ("Natural"). ${ }^{54}$ In that decision, the ERA allowed Natural to import Canadian natural gas in accordance with its agreement with ProGas Limited ("ProGas") and allowed the pass-through of the two-part demand/commodity rate structure contained in that agreement. ${ }^{\text {ss }}$

The initial decision of the Administrative Law Judge ${ }^{56}$ also permitted full "as-billed" pass-through by Natural of the demand charge negotiated in its amended contract with ProGas.

In December, 1986, the Federal Energy Regulatory Commission (the "FERC") reversed the initial decision of the Administrative Law Judge by virtue of Order No. 256. ${ }^{57}$ FERC Order No. 256 directed Natural to modify its demand charge to exclude all fixed costs associated with return on equity and related taxes ${ }^{58}$ and exclude NOVA's charges to ProGas. ${ }^{99}$ The FERC ordered the removal of NOVA charges from Natural's demand charge on the basis that "neither ProGas nor TransCanada is obligated to pay demand-related dollars to NOVA" ${ }^{\prime 60}$ and that it would, therefore, be "patently unreasonable to require American distributors and consumers to

52. Id., attachment to letters at 3 and 4.

53. For a full discussion of U.S. regulatory matters relating to deregulation, see A. R. Madigan, D. A. MacDonald, D. R. Dornan and H. C. Rosenthal, Jr., "Regulation and Deregulation of the Natural Gas Industry in the United States" (1986) XXV Alta. L. Rev. 2.

54. 1 E.R.A. 9. 70,645 (1986).

55. Id. at 72,532 and 72,533 .

56. 35 F.E.R.C. $9.63,054$ (1986).

57. Federal Energy Regulatory Commission, Docket Nos. TA85-1-26-004, 005, "In the Matter of Natural Gas Pipeline Company of America, Opinion No. 256, Opinion and Order Reversing Initial Decision" (1986).

58. Id. (Order and Opinion) at 18.

59. Id. (Order and Opinion) at 19.

60. Id. (Order and Opinion) at 19. 
pay demand charges to Natural with respect to NOVA". ${ }^{61}$ The FERC ordiered the removal of these charges from Natural's demand charge despite the negotiated nature of the contract and despite take-or-pay provisions being relinquished by ProGas as part of those negotiations, because the FERC concluded that such denial was necessary to ensure that Canadian and U.S. gas supplies are afforded equal treatment and that cost recovery provisions "achieve reasonable results". ${ }^{62}$

Order 256 has generated a storm of controversy on both sides of the border and, within Canada, at both the provincial and national levels. Allegations have been made that the FERC is attempting to exercise extraterritorial jurisdiction to impose its policies upon Canada. The Canadian Government has expressed its concern directly to the White House. The U.S. State Department has warned that Order 256 may jeopardize freetrade talks with Canada ${ }^{63}$ The potential detriments to Canadian producers have been estimated at between $\$ 140$ million and $\$ 400$ million in reduced netbacks. ${ }^{64}$

It should be noted that one of the justifications for reversing the initial decision of the Administrative Law Judge no longer exists. As discussed above, effective November 1, 1986, NOVA's tolls became two part, including a fixed cost demand charge. This change was recognized by the FERC in its Order 256A, ${ }^{65}$ wherein the FERC reaffirmed its decision in Order 256, but attached weight to the evidence respecting NOVA's amended tariff schedules and allowed the pass-through by Natural Gas Company of America to its customers those amounts relating to NOVA's demand charges, on an "as-billed" basis.

\section{CONCLUSIONS}

Significant progress has been made since the execution of the October 31, 1985 Intergovernmental Agreement toward creating a more market sensitive pricing regime for natural gas, both in Canada and with respect to the export market. However, several of the matters contemplated by that Agreement have not yet been concluded, most significantly the outcome of the current NEB Surplus Determination hearing. Additionally, the firm capacity problem on the NOVA system could well restrict accessibility of direct shippers of gas to both domestic and export markets. Finally, the ramifications of FERC Orders 256 and 256A on the competitiveness of Canadian natural gas in U.S. markets are unascertained at present.

61. Id. (Order and Opinion) at 19.

62. Id. (Order and Opinion) at 19 and 20.

63. "Daily Oil Bulletin" 29 April 1987 at 1.

64. Id.

65. Federal Energy Regulatory Commission, Docket Nos. TA85-1-26-006, 007, 008, 009, 010, 011,012 and 013, "In the Matter of Natural Gas Pipeline Company of America, Opinion No. 256-A, Opinion and Order Granting in Part and Denying in Part Rehearing and Clarifying Opinion No. 256" (May 27, 1987). 


\section{APPENDIX A}

Alberta Natural Gas Sales for 1986 and 1985

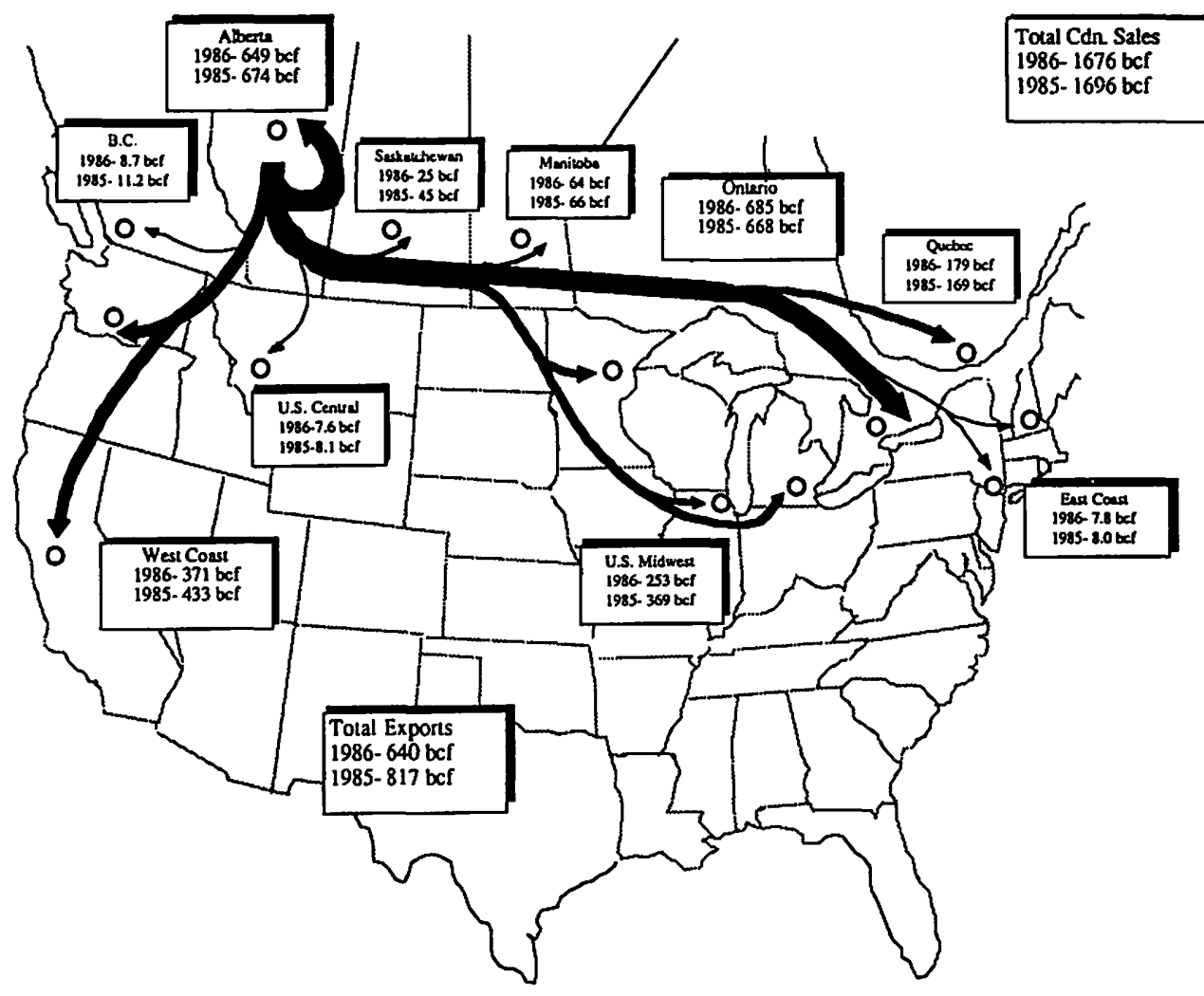

Reproduced with the permission of The Alberta Petroleum Marketing Commission 


\section{APPENDIX B}

major canadian

NATUIRAL GAS PIIPRLINIE SYSTTLMS

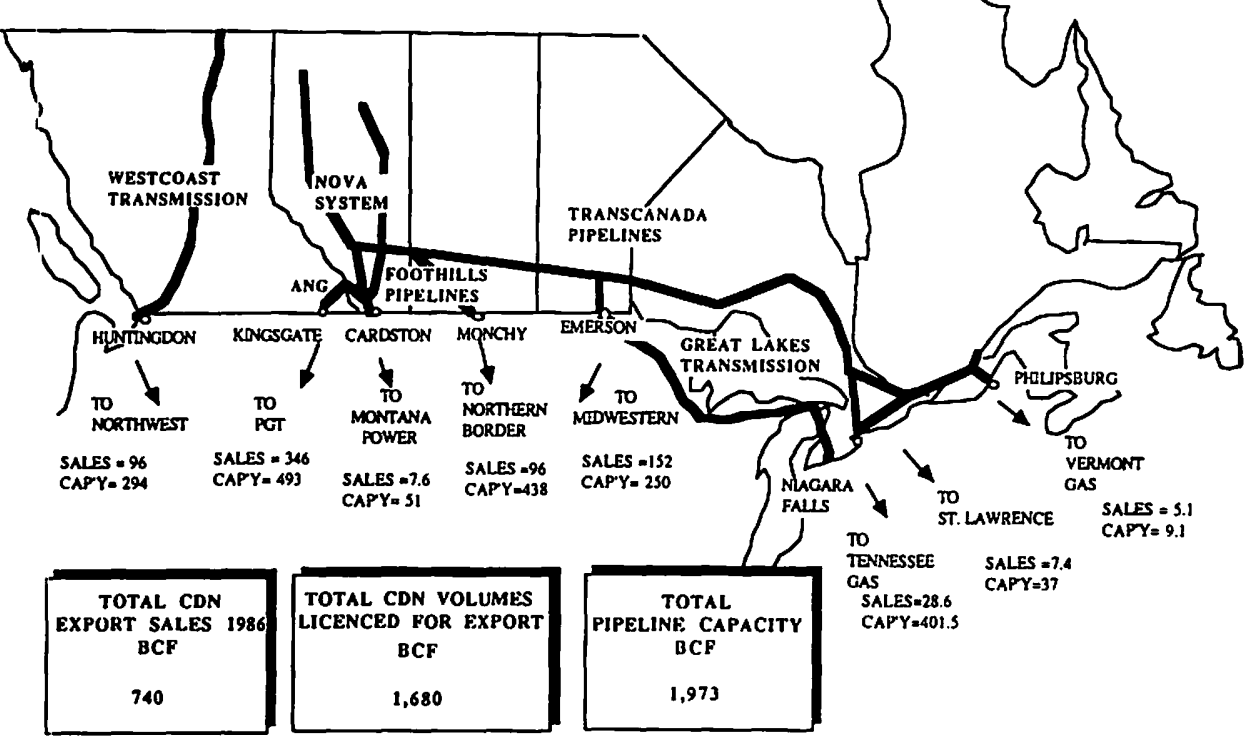

Reproduced with the permission of The Alberta Petroleum Marketing Commission 
[VOL. XXVI, NO. 1

\section{APPENDIX C \\ TCPL SYSTEM REQUIREMENTS VERSUS CAPACITY \\ CONTRACT YEAR 1988/89' \\ WINTER PEAK DAY}

Section

Western

Great Lakes

East of Station 41

Central Section

Great Lakes

Total Capability at

Dawn

North Bay Shortcut/

Montreal Line

Niagara

(Lisgar - Niagara)

Iriquois Extension
Requirements ${ }^{\mathrm{i}}$ $\left(10^{6} \mathrm{~m}^{3} / \mathrm{d}\right)$

124.1

$10.90^{\text {i3 }}$

78.04
Capability $^{\mathrm{ii}}$ $\left(10^{6} \mathrm{~m}^{3} / \mathrm{d}\right)$

130.19

35.41

61.11

$\underline{24.51^{\text {iv }}}$

85.61

39.94

42.12

13.36

13.37

10.24

NOTES:

i All figures from or based upon TCPL 1988 Facilities Application, Tab "Facilities", Sub-tab 2, Tables 1, 2, 3 and 4.

ii TCPL 1988 Facilities Application also refers to summer peak day, winter season, summer season and annual requirements and capacities as being relevant considerations, due to existence of ACQ volumes.

iii Existing exports.

iv Total Great Lakes winter peak day capacity of $35.4110^{6} \mathrm{~m}^{3} / \mathrm{d}$, less existing exports of $10.9010^{6} \mathrm{~m}^{3} / \mathrm{d}$. 